\title{
Acacia Catechu Trees in Rice Fields: A Traditional Agroforestry System of Northern Bangladesh
}

\author{
Md. Alamgir Kabir (Corresponding Author) \\ Department of Agroforestry, Patuakhali Science and Technology University \\ Dumki, Patuakhali -8602, Bangladesh \\ Tel.: +88 04427-56014/468, Fax: +88 04427-56009, E-mail: alamgirmk@gmail.com \\ K.M. Masum Billah \\ Department of Plant pathology, Patuakhali Science and Technology University \\ Dumki, Patuakhali -8602, Bangladesh \\ Tel.: +88 01753946495, Fax: +88 04427-56009, E-mail: masumkhan888.mk@gmail.com \\ Md. Masud Parvez \\ Faculty of Agriculture, Patuakhali Science and Technology University \\ Dumki, Patuakhali-8602, Bangladesh \\ Tel.: +88 01720333661, Fax: +88 04427-56009, E-mail: mdparvezmasud1201087@gmail.com
}

(Received: June 1, 2015; Reviewed: Aug 8, 2015; Accepted: Sept 1, 2016)

\begin{abstract}
Growing Acacia catechu trees on rice fields is one traditional crop-land Agroforestry system of Rajshahi region in Bangladesh. Farming system was explored with detailed information on farm operations and cropping calendar including system outputs. System dynamics was also evaluated. PRA exercises were conducted for a biophysical assessment. The information was collected on informant wise and cross-checked. Best growth of trees observed under rain-fed conditions. Higher density of trees found in un-irrigated fields. Trees were better managed in small plots. In general, density of khoir trees was found higher in small holdings (less than 2 ha) with secured land tenure. Trees on farms were of uneven age indicating the khoir + rice system biologically sustainable. The ease of establishment of Khoir seedlings, the low cost of its maintenance, and less vulnerability to any serious pest or disease, easy marketability of products rated high in the farmer's preference for khoir. They appreciate the versatility of the wood for a variety of farm uses though its prime economic use to them is for production of lali for katha. They also get pitch khoir as by product of katha (red dyestuff for textiles and paper) production. The multiple products and services offered and the ease of managing the trees on crop fields without causing any immediate or long-term reduction in crop yield seemed to be the most important factors that encourage the farmers to continue this traditional practice. If farmers could be motivated to follow appropriately the silvicultural practices, production could further be increased.
\end{abstract}

Keywords: Acacia catechu; farming-systems analysis; indigenous systems; Participatory Rural Appraisal; Pitch Khoir 


\section{Introduction}

Agroforestry is one of the most conspicuous land use systems across landscapes and agroecological zones of Bangladesh and tropical Asia, and also in African countries. Some forms of agroforestry require low external inputs (pro-poor), have a high recycling rate, and good integration of trees, crops and animals, making them good candidate for achieving both sustainable livelihood and climate changes objectives (Koohafkan et al., 2012). In light of the high potential of agroforestry for food security, climate change adaptation and mitigation, tree-based agricultural systems are currently being promoted in many parts of Africa (Garrity et al., 2010). Cropland agroforest is also an important production system in the southwest region of Bangladesh (Hasanuzzaman et el., 2014) and also on northern districts.

Acacia catechu Willd. is a common tree found on farmlands as well as in wastelands and roadsides in northern Bangladesh. In the Rajshahi region (Figure 1), the tree has a special significance to resource-poor farmers, who have a long tradition of growing it on their farms along with crops. The overall contribution of trees to local farming system is complex and subtle, including non-tangible benefits such as improvement in microclimate, inputs through leachates and nutrient cycling (Young, 1997). Intercropping under scattered trees is the simplest and most popular form of agroforestry under smallholder management (Nair, 1993). A multitude of indigenous systems involving a large number of different trees has been reported from different parts of the trop- ics. Examples include Faidherbia albida in semiarid West Africa (Vandenbeldt, 1992), Vitellaria paradoxa (Karité) and Parkia biglobosa (Néré) trees in semiarid sub-Saharan Africa (Breman and Kessler, 1995), poplars (Populus spp.) with wheat in northwestern parts of India (Khybri et al., 1992) and Prosopis cineraria (khejri) with millets in Rajasthan, India (Sankaranarayanan et al., 1987; Tejwani, 1994). Usually, such species that are maintained or deliberately grown in crop fields do not receive or require much canopy-management operations especially during the cropping seasons, and they provide multiple products and services. Jambulingam and Fernandes (1988) documented the cultivation of Acacia catechu trees on rice bunds (raised risers) in Tanjavur and Thiruchirapalli districts of Tamil Nadu State of India.

Reports of Bangladeshi trees that are deliberately maintained in rice (Oryza sativa) fields are scarce though Hocking and Islam (1995) reported growing of Acacia nilotica, Acacia catechu and Borassus flabellifer in paddy fields and Rahman and Alam (2007) reported composition and benefit of cropland Agroforestry of Rajshahi. Ferdouse et al. (2009) reported production processing and marketing of khoir. Though some more reports on the practice of maintaining Acacia catechu tree in rice fields in northern Bangladesh are also available (Puri et al., 1994; Viswanath et al., 1998), they are mostly descriptive in nature. The value of the tree has, however, been not properly documented through systematic studies. Improving the practice of local knowledge to generate productivity without damaging 
practices and values that are conducive for local or indigenous knowledge is one of the important components in the development process (Husnah et al., 2014). Indeed, being a traditional low-input system, it does not find a place in the agenda for agricultural development that focuses on 'progressive' activities, often involving 'modern' technologies. Studies on such existing traditional practices revolving around indigenous trees of proven value on croplands may provide insight into the underlying reasons for farmers' preferences and adoption of new agroforestry practices. Almost everything about the tree and the agroforestry system, of which it is the major component, is scientifically little- or unknown. A major opportunity lies in tree improvement. Just like several other species of Acacia and other MPTs in indigenous agroforestry systems around the tropics (Nair, 1989), Acacia catechu is a little-studied species. Its uses and potential have not been even fully recognized, let alone exploited. This paper presents a farming-system analysis to describe the structure and functioning of Acacia catechu -based agroforestry system and examines the close relationship that exists mong the tree, agricultural crop and domestic animals in local farming practices.

(Note: Being a 'system-description' study, the presentation does not follow the 'Introduction-Materials and Methods-Results-Discussion'format.)

\section{Materials and Method}

The Rajshahi region, where the system is being practiced extensively, is predominantly subsistence agricultural region in the northern part of Bangladesh. The region has a geographical area of $2407.01 \mathrm{sq} \mathrm{km}$, located in between $24^{\circ} 07^{\prime}$ and $24^{\circ} 43^{\prime}$ north latitudes and in between $88^{\circ} 17^{\prime}$ and $88^{\circ} 58^{\prime}$ east longitudes (Figure 1). It is bounded by Naogaon district on the north; west bengal state of India, kushtia district and Ganges river on the south; Natore district on the east, Nawabganj on the west. The climate is sub-humid with an average annual rainfall of about $1400 \mathrm{~mm}$; mean annual temperatures vary from $31.6^{\circ} \mathrm{C}$ to $19.9^{\circ} \mathrm{C}$ (range $48^{\circ} \mathrm{C}$ to $4^{\circ} \mathrm{C}$ ) and atmospheric humidity from $51 \%$ to $69 \%$ (range $85 \%$ to $26 \%$ ). The region consists of Barind tract, Diara and Char lands.

Most soil groups of Rajshahi are highly suited for rice cultivation. Agriculture of this region still largely depends on rainfall. Rice is the principal crop and cultivated sometimes with $A$. catechu tree, locally known as khoir; that name will be used here after in this paper to refer to the tree. The information on the traditional system reported here was obtained through the researchers' insightful observations and close interactions with the farmers during a two-year period in four locations: Charghat, Putia, Paba and Boalia in Rajshahi. Additionally, structured questionnaire survey was conducted at Charghat upazila of Rajshahi following stratified random sampling method in 25 villages, covering 200 farm families, at one percent sampling intensity. These results were then iterated using semi-structured questionnaire following PRA (Participatory Rural Appraisal) methods (Hildebrand, 1981; Chambers et al., 1989; Poffenberger et al., 1992). Four categories of respondent farmers were selected at random from each 


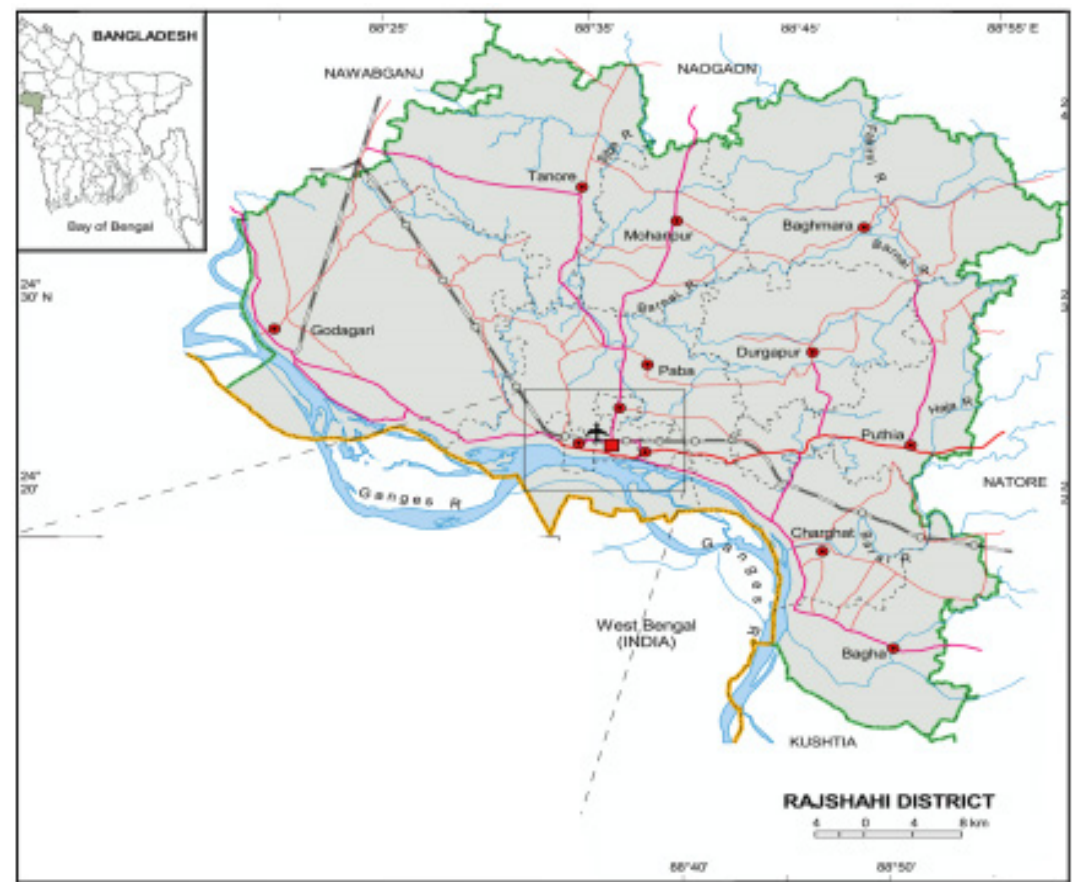

Figure 1. Map of Bangladesh showing study region (Charghat, Putia, Paba and Boalia in Rajshahi).

village, based on the size of their landholdings: $<2$ ha (marginal), 2 to 4 ha (small), 4 to 8 ha (medium) and $>8$ ha (large). The questions covered a large number of parameters including tree growth characteristics, crops and cropping calendar, socio-economic information, and market related aspects.

\section{Results and Discussion}

\subsection{Systemic Description}

\subsubsection{The trees}

The Khoir trees are an integral part of the small farm holdings in the study region. They are maintained as scattered trees in crop fields. Farm animals have a role in the natural regeneration of khoir trees in crop fields: the seeds eaten by the animals pass through their system and end up in dung heaps scattered as farm yard manure (FYM) in the field. With the onset of rains in June, the seeds germinate and profuse stands of seedlings appear throughout the field. The stand is then thinned down to the desired tree density and spacing in the field. For young trees, a spacing of about $5 \mathrm{~m}$ between trees is considered optimum. This facilitates ploughing operations using bullocks. At the end of the fifth year, the tree spacing may be increased to nearly $10 \mathrm{~m}$ by thinning. A well-defined division of labour along gender seems to exist within the household for the care and management of trees. Canopy- and root-pruning is done primarily by men, while collection and transport of the pruned material are done by women and children. Pruning commences in the third year of establishment of the tree and a regular activity every summer until tree harvesting. The trees are pruned initially to promote the formation of clean straight bole that can fetch premium price in the market. The crown is maintained high and light by pruning off lower branches so that the shade cast on understory crops is minimized. Decisions on whether to maintain an even- or uneven-aged stand of trees by retaining older trees may depend on other 
factors like anticipated cash requirements to meet expenses such as marriage in the family or pay off of term loans. On average, a farm had 20 khoir trees and almost an equal number of other trees per hectare. The numbers of both the khoir and other trees droped to about 10/ha each on 'large' farms (> 8 ha). Higher densities of khoir (60 to 120 trees/ ha) inside crop fields may also be observed in small farms ( $<2$ ha).

\subsubsection{The crops}

As mentioned, rice is the main crop of Rajshahi region. Sowing of medium- and long-duration local rice varieties and cultivars is done during July along with a second ploughing. A variety of grain legumes and vegetables are planted on the wide bunds between rice fields depending on the proximity of fields to the household. Among the grain legumes (usually called pulses) on the bund, the most common is pigeon pea (Cajanus cajan). Occasionally oil seed crops such as linseed (Linum usitatissimum) and sesamum (Sesamum indicum) are also planted on the bunds. A multitude of vegetable crops like egg plant (Solanum melongena), tomato (Lycopersicon esculentum), cowpea (Vigna ungiculata) and chilli pepper (Capsicum annum) are sown on the bunds of fields near homes to meet subsistence needs.

\subsubsection{The animals}

Cattle are an integral part of the farm household in Rajshahi. During cropping season (June to December), the local grazers tend the cattle in village common lands on monthly rental basis. Untended cattle found grazing in standing crop fields are rounded up in village cow sheds and a penalty is levied on the owners by the local governing body (Union Parishad) depending on extent of crop damage. Cattle are allowed to graze freely in crop fields only during the dry months when they are often found resting beneath Khoir trees. The cattle eat the fallen mature pods of Khoir trees and subsequently the seeds are dispersed throughout the fields as dung heaps. Seeds in dung heaps appear to germinate faster than normally dispersed seeds, due to scarification in the alimentary canal of the animals. Draft power is used in agricultural operations like ploughing and threshing of rice grain (cattle are made to trample on the harvested stalks in a rotary motion to separate the grains). Dung cakes made in dry season supplement firewood from khoir trees as cooking fuel. An average household of five members would require 5 $\mathrm{kg}$ of firewood and two to three dung cakes daily.

\subsubsection{Farm operations and cropping calendar}

Rice seedlings are uprooted, bundled and later transplanted evenly throughout the field. Thinning of regenerating 'khoir' seedlings is also done during this time to get a fairly uniform stand of desired density. For maximum utilization of rainfall, farmers traditionally practise a kind of relay cropping where seeds of khesaridal (Lathyrus sativus) or linseed are broadcasted in rice fields by the end of September, about a month before harvesting of rice. The rice crop is harvested in October leaving a 30 to $40 \mathrm{~cm}-1$ ong stubble, taking care not to damage the low spreading relay crops. Although yield of relay crop is low (150 to $200 \mathrm{~kg} / \mathrm{ha}$ ), farm- 
ers consider it as a bonus to be utilized for household consumption in times of drought or as a cattle feed concentrate.While most of the agricultural activities commence with the onset of rain in June, major activities related to khoir tree management are completed before the rain (Table 1). A clear picture of crop growth emerges by the end of September. Occasionally the rice crop may lodge below trees that had not been properly pruned. Lodging may also occur due to etiolation from excess shade. Farmers believe that crop lodging is an indication of excessive $\mathrm{N}$ uptake following increase in $\mathrm{N}$ levels below tree canopy as a consequence of decomposition of the fallen tree litter. Farmers also believe that trees have some ability to enhance soil fertility beneath them; perhaps the reference is to nitrogen fixation. If excessive vegetative growth is noticed beneath tree canopies, leaves of rice crop are clipped before boot-leaf emergence.A second light weeding is performed if deemed necessary. Crop fields may also harbour fish that may have entered the field in floodwaters during July. When the rainfall tapers off in September, fields start to dry off and water is stored in small depressions in the field. This drainage may concentrate the fish population and make their collection easier. At the end of September, soil moisture also starts to decrease. By the time the rice crop is matured the relay crop usually established itself at the understory. Labour hired for rice harvesting

Table 1. Calendar of farm activities in khoir $($ A. catechu $)+$ rice agroforestry system in Rajshahi.

\begin{tabular}{|c|c|c|c|c|c|c|c|c|c|c|c|c|}
\hline Activities & $\mathbf{J}$ & $\mathbf{F}$ & $\mathbf{M}$ & $\mathbf{A}$ & $\mathbf{M}$ & $\mathbf{J}$ & $\mathbf{J}$ & $\mathbf{A}$ & $\mathbf{S}$ & $\mathbf{A}$ & $\mathbf{N}$ & D \\
\hline Land leveling & & & & $*$ & $*$ & & & & & & & \\
\hline Collection \& burning of stubbles & & & & & & $*$ & & & & & & \\
\hline Summer ploughing & & & & & $*$ & & & & & & & \\
\hline Application of FYM & & & & & & * & & & & & & \\
\hline Ploughing and broadcast of rice & & & & & & & $*$ & & & & & \\
\hline First weeding & & & & & & & & $*$ & & & & \\
\hline $\begin{array}{l}\text { Fertilizer application \& plant } \\
\text { protection }\end{array}$ & & & & & & & & & $*$ & & & \\
\hline Sowing of relay crop & & & & & & & & & $*$ & & & \\
\hline Rice harvest \& bundling & & & & & & & & & & & $*$ & \\
\hline Threshing, winnowing \& bagging & $*$ & * & & & & & & & & & & \\
\hline Harvest of Relay Crop & $*$ & & & & & & & & & & & \\
\hline Threshing \& Winnowing & & $*$ & & & & & & & & & & \\
\hline \multicolumn{13}{|l|}{ For Khoir Trees } \\
\hline Seed germination & & & & & & $*$ & & & & & & \\
\hline Inital Seedling Establishment & & & & $*$ & & & & & $*$ & & & \\
\hline Canopy Management and Pruning & & & & & $*$ & & & & & & & \\
\hline Fuel wood collection & & & & & $*$ & & & & & & & \\
\hline Biofencing & & & & & $*$ & & & & & & & \\
\hline Root Pruning & & & & & $*$ & & & & & & & \\
\hline Branch Pruning & & & & & & & & & & $*$ & & \\
\hline Seed Collection & & & & $*$ & $*$ & & & & & & & \\
\hline Thinning & & & & $*$ & $*$ & & & & & & & \\
\hline Harvest \& Extraction & & * & $*$ & $*$ & $*$ & & & & & & & \\
\hline
\end{tabular}


is paid in cash or in kind (usually a 'headload' of harvested produce) or both. Threshing and winnowing operations for rice are done simultaneously. Sale and transactions in khoir trees also happen during the period from February to May. Tree management activities like canopy and root-pruning are done during the dry months. Collection of tree products and seeds is done during AprilMay. Staking of seedlings (in August) and secondary branch pruning (in September) are the only tree management activities done during the main cropping period.

\subsection{System Outputs}

The khoir tree yields a multitude of products during its life span. The main product of khoir tree is katha (lali). The yield and price of katha is different at different age of the tree (Table 2). Maximum yield and price of katha is obtained at the age of 36-40 year and minimum yield and price of katha is obtained at the age of 10-15 year. But majority of tree growers fell their khoir trees at the age of 21-25 to obtain different products in relatively short rotation period and most of them are ignorant about the optimum age for maximum yield. A conceptual model of the rice + khoir system linking various farm activities and operations has been shown in Figure 2. This model was developed based on extensive field observations in the study region and analysis of data, primarily as an aid in understanding the linkages among various aspects and components of the system and role of each component.

Family labour is used in most agricultural operations from land preparation to final harvest and threshing. Hired labour is used, though in a limited scale, for activities like transplanting, weeding, plant protection, and harvesting of rice crop, and extraction (harvest) of mature khoir trees (Figure 3).

Cash could be in the form of crop loans for purchase of fertilizers, feed concentrates or for some specific household activities. When tree canopy is low and vigorously growing, they need frequent pruning and farmers need to come in close contact with them for farming operations. Hired farm laborers decline to work near such trees or demand extra wages to compensate for the hazardous task and painful bruises and scratches they might sustain. Thorniness is also a problem in managing adult trees during operations such as branch pruning and collection and transport of fuel wood and brushwood.

Table 2. Yield and price of khoir tree and katha of various age class and diameter at breast height (dbh) [values are mean of five observation with standard error of mean]

\begin{tabular}{cccccc}
\hline \multirow{2}{*}{$\begin{array}{c}\text { Age class } \\
\text { (year) }\end{array}$} & $\begin{array}{c}\text { dbh } \\
(\mathbf{c m})\end{array}$ & $\begin{array}{c}\text { Price/Tree } \\
\text { (Tk.) }\end{array}$ & $\begin{array}{c}\text { Heartwood } \\
\text { Chips }(\mathbf{k g})\end{array}$ & \multicolumn{2}{c}{ Katha (Lali) } \\
\cline { 6 - 7 } & $17.38 \pm 1.40$ & $500.00 \pm 70.7$ & 120 & 13.5 & 1080.00 \\
$10-15$ & $20.52 \pm 1.24$ & $830.00 \pm 75.83$ & 136 & 16.10 & 1288.00 \\
$21-25$ & $22.9 \pm 2.063$ & $1500.00 \pm 117.26$ & 225 & 32.20 & 2576.00 \\
$26-30$ & $25.5 \pm 1.60$ & $2360.00 \pm 251.11$ & 435 & 62.24 & 4979.2 \\
$31-35$ & $27.6 \pm 1.56$ & $3300.00 \pm 212.13$ & 540 & 72.10 & 5768.00 \\
$36-40$ & $30.91 \pm 2.07$ & $4800.00 \pm 758.29$ & 730 & 91.05 & 7284.00 \\
\hline
\end{tabular}




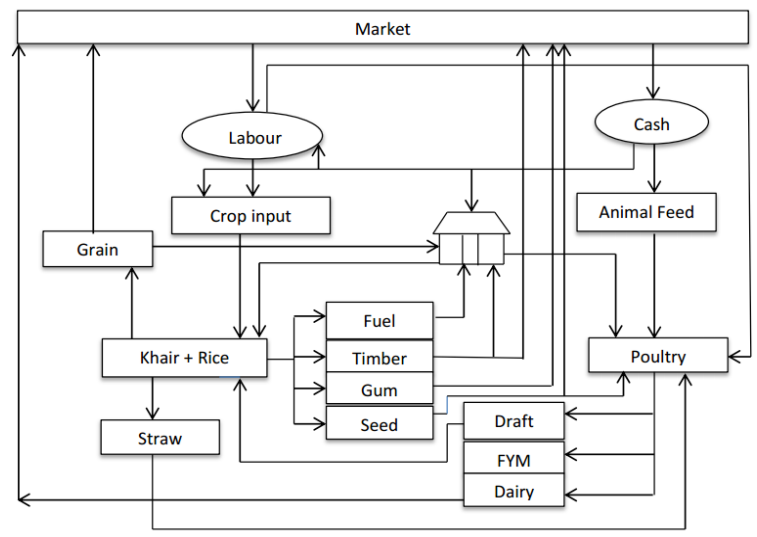

Figure 2. Schematic representation of the 'khoir' $($ Acacia catechu $)+$ rice agroforestry system in Rajshahi

3.2.1 Harvesting, chipping and processing for production of khoir

Generally, 15 years old trees are harvested. Harvesting is done by uprooting the entire tree to as deep as possible. After felling the tree, all small branches and twigs are removed and logs are prepared by bucking. The $\log$ is then debarked completely including sap wood using axe. The remaining heartwood is then chopped into small chips (locally known as chilled). The chips are boiled twice for a period of thirty minutes each. After each boiling process, the juice is transferred to a pan for further boiling usually for two hours to get more concentrated lali / katha. Processors sometimes mix wheat flour or china clay to make higher concentration and weight of katha. When the katha (Lali) becomes further thick and fully concentrated after further being stored in big earthen pot for evaporation, it is brought to the market for selling. There are four types of katha viz. grade A, B, C, D in the local industries. The pure katha named grade A. The ranking or other grades depends and quality of china clay.

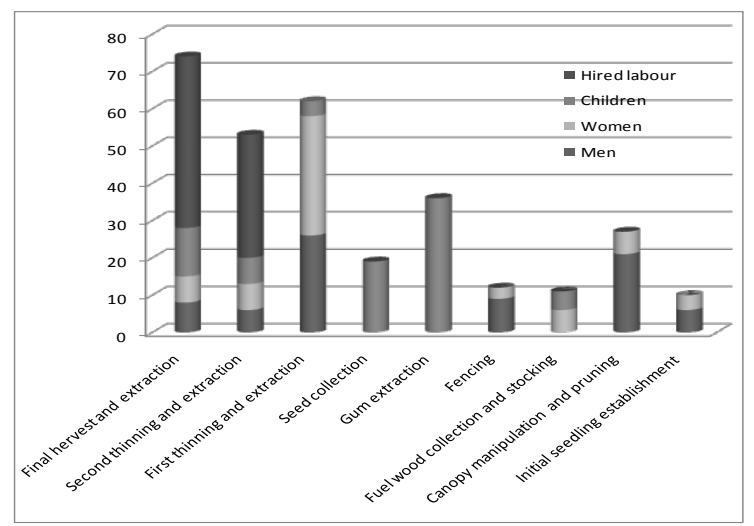

Figure 3. Utilization of hired and family labour in tree husbandry of khoir + rice agroforestry system in Rajshahi

For preparing guti khoir, katha (lali) is pressed manually by specially designed machine consisting of two steel plates of $15 " \times 15$ " to remove excess water within katha and 15 " $\times 15$ "guti khoir sheets are produced. Air-dried guti khoir sheets are either sold directly to market or placed in the rack for further drying for another two months after making small pieces and applying preservative powder. After which the catechu (guti khoir) becomes ready for sale. The chuani (the amount of water come out during pressing is locally known as 'Chuani') extracted during pressing of katha is used for preparation of inferior quality catechu called 'Pitch khoir'. The chuani is mixed with baking powder and china clay or wheat flour and is concentrated by boiling and is brought to market for selling. A flow-chart of Khoir / catechu processing by country method has been provided in Figure 4. Primary market of Khoir trading is Charghat and secondary market is Dhaka. Seven types of players were identified in the whole marketing channel with their role and relationships as described as flow chart (Figure 5). In the ex- 


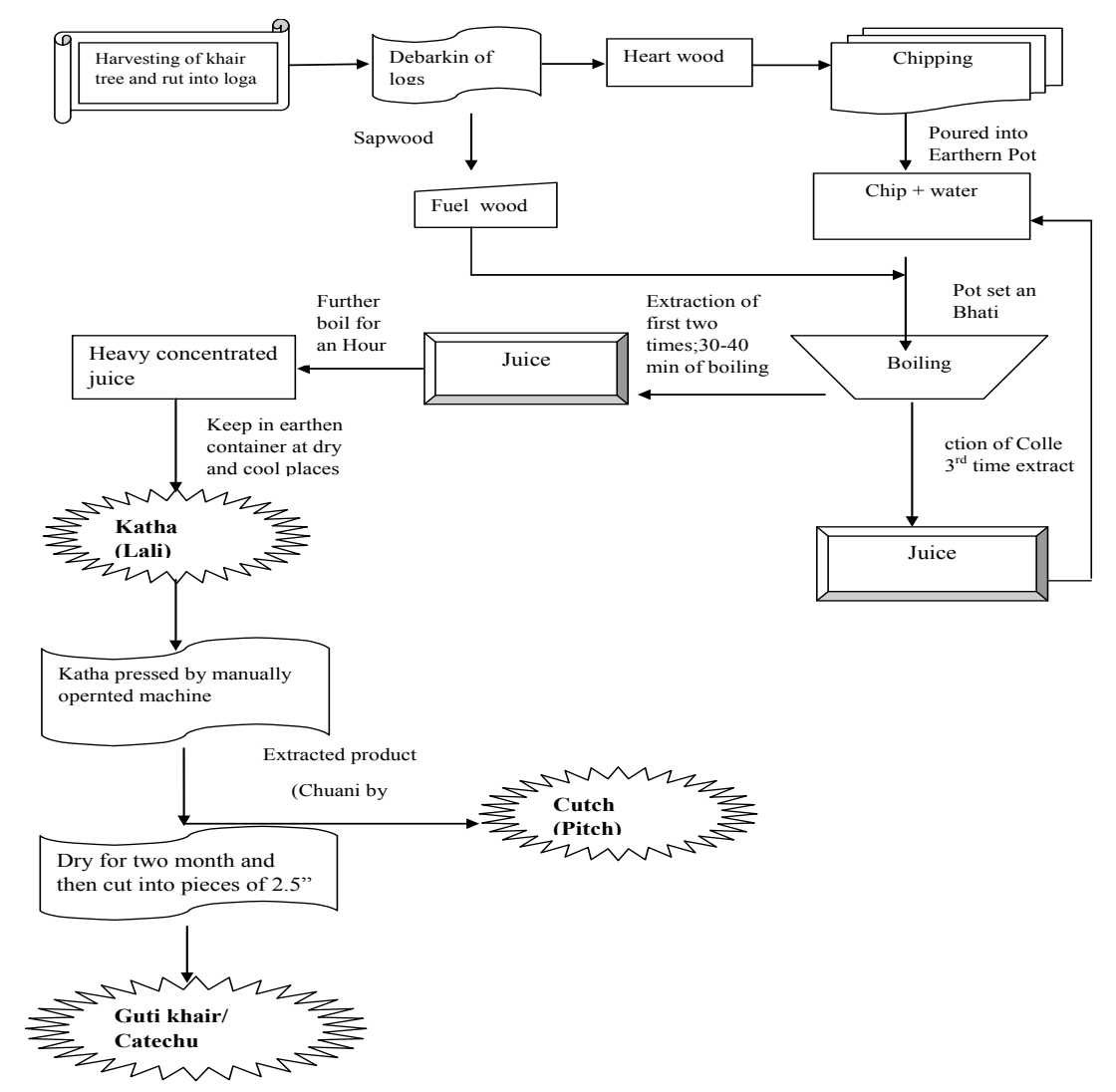

Figure 4. Flow-chart of Khoir / Catechu processing by country method.

isting marketing system, maximum profit is earned by middle men (44\%), irrespective of investment (Figure 6) and the lowest is earned by retailer $(10 \%)$.

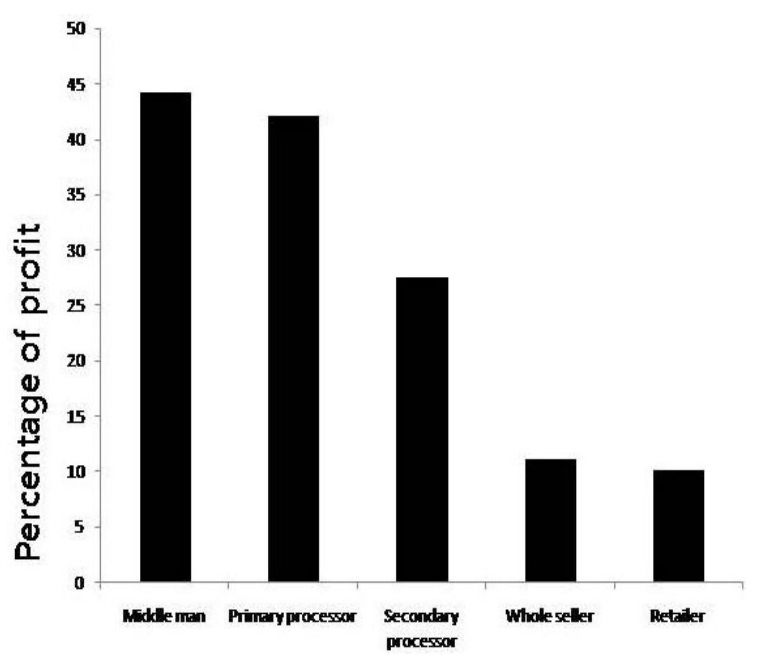

Figure 6. Percentage of profit earned at different level of marketing of Katha and Catechu by different agents

\subsection{PRA (Participatory Rural Appraisal)} Analysis

PRA exercises were considered necessary for a biophysical assessment of tradi- tional agroforestry practices and to garner information on social, economic, political and legal aspects of tree planting and its management at village community level. The information on khoir trees was disaggregated informant wise, cross-checked and the main factors which tend to explain the high density of khoir trees in crop lands identified (Table 3). While most of the factors like soil type, landholding size, tenure, risk susceptibility and market accessibility had a direct causal relationship with tree density; irrigation was found to have an indirect or inverse relationship. The PRA results seemed to indicate an inclination of smallholder (subsistence) farmers to go in for trees like khoir in high density planting configurations in absence of other sources of income. The main factors identified in the PRA exercises appear to exert considerable 


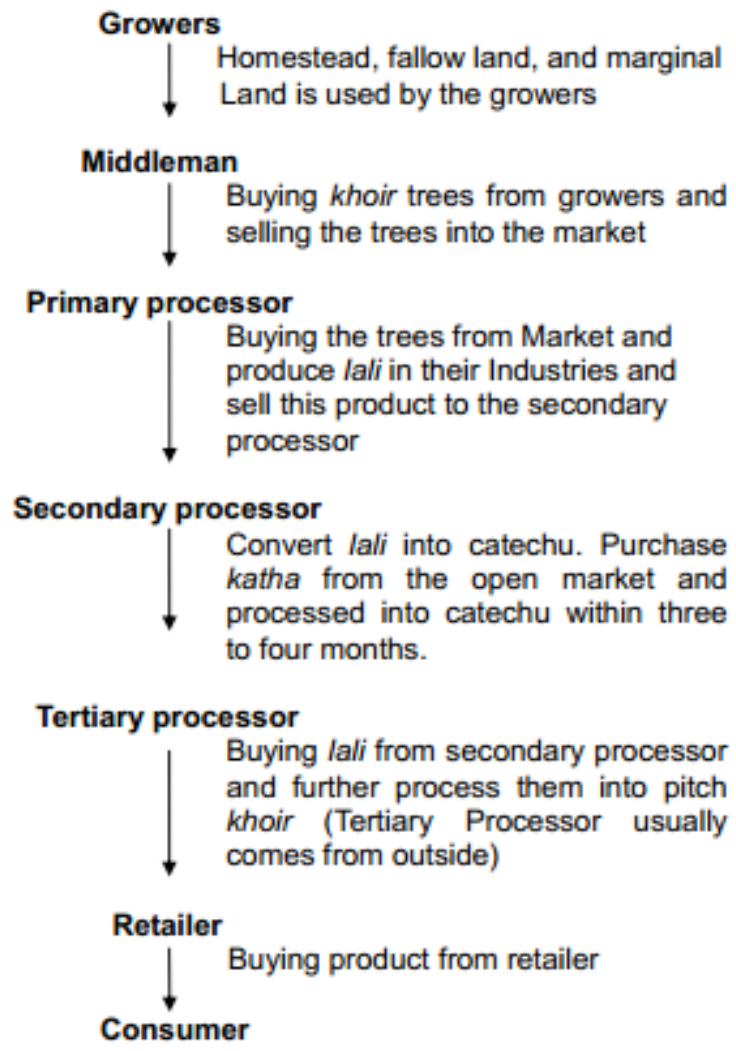

Figure 5. Flow-chart showing marketing channel of Khoir from Growers to Consumers

influence on farmers' decision to practice the khoir + rice system as seen in Rajshahi.

\subsection{System Dynamics and Evaluation}

Although the practitioners of this traditional system are poor subsistence farmers, they are highly skilled in maintaining trees on their crop fields without compromising their food security system from rain-fed agriculture. From sapling stage of tree growth, the main stem is manipulated through pruning with twin objectives of obtaining an umbrella shaped crown with maximum length of straight bole and keeping the canopy as high as possible to minimize shading of rice crop. Root pruning through ploughing carried out during the first summer ensures that the lateral- and feeder roots do not come close to the surface to compete with shallow rooted agricultural crops for water and nutrients. The extended lateral roots of trees can be detected when the ploughshare gets obstructed during ploughing operations. Branch pruning carried out during September ensures that the new grown lateral shoots do not cause obstruction to farming operations. The extent of above- and below-ground interactions between the khoir tree and the rice crop in this system can be expected to follow the general patterns of such interactions in agroforestry systems as described by Rao et al. (1998). The sparse canopy of scattered trees is unlikely to cause any serious shading of rice crop at tree densities practised by the farmers. As far as root competition is concerned, there are contrasting views among 
researchers.

It was commonly believed that the deep rooting behaviour of trees helped minimize competition for resources with shallow-rooted agricultural crops. However, recent research results and conjectures suggest that most of the fine feeder roots of MPTs in agroforestry systems are also concentrated within the top $20 \mathrm{~cm}$ of soil (Van Noordwijk et al., 1996; Schroth, 1999). This highlights the need for screening the root system of tree species used in agroforestry systems, especially in systems like scattered trees on croplands. The khoir tree can be competitive to associated crop plants in arid or semiarid environments but, in sub-humid conditions of Rajshahi region, where farmers even resort to lateral root pruning, competition of trees with crops for water is not likely to be a serious problem.

As regards soil fertility, Nair et al. (1999) identified three major avenues of soil fertility improvement mediated by trees in agroforestry systems - nutrient addition through tree-litter, biological nitrogen fixation, and uptake of nutrients from deeper soil layers by tree roots and their deposition on soil surface through nutrient cycling. These are likely to be operational under this system too, as clearly evidenced by visually better growth of rice under trees. The tree's demand for nutrients could be highest during stages of its foliage expansion and root growth that happens during the initial periods of growth. Therefore, tree-crop competition for nutrients and water is likely to be most severe during early stages of tree growth, and reduction in crop yields, if any, is likely to occur during the early part of rotation period. If the tree is pruned annually for firewood, as in the case of Acacia catechu, the resultant nutrient exports in harvested fractions might increase competition between trees and associated crops when the trees compensate for exported nutrients. However, in the later stages of tree growth, crop yields may stabilize as in this system. If decline in crop yields happens during the latter half of

Table 3. Factors influencing potential density of Acacia catechu trees in rice fields in Rajshahi.

\begin{tabular}{|c|c|c|}
\hline $\begin{array}{l}\text { SI } \\
\text { no. }\end{array}$ & Factors & Influence on farm decisions favouring the Khoir + Rice \\
\hline 01 & Irrigation & $\begin{array}{l}\text { Best growth of trees is under rain-fed conditions. Higher density of trees } \\
\text { was seen in un-irrigated fields. Density of trees inside crop fields was } \\
\text { founds to be adversely affected due to Ganoderma root rot disease in } \\
\text { irrigated fields. }\end{array}$ \\
\hline 02 & Soil type & Best growth of khoir is in vertisol soil types. \\
\hline 03 & Holding size & $\begin{array}{l}\text { Trees could be better managed in small plots. In general, density of khoir } \\
\text { trees was higher in small holdings (less than } 2 \text { ha) }\end{array}$ \\
\hline 04 & Land tenure & $\begin{array}{l}\text { When the cultivated field is leased out or given on rent, low priority is } \\
\text { accorded for retaining trees inside upland rice fields. }\end{array}$ \\
\hline 05 & Risk susceptibility & $\begin{array}{l}\text { Small holder farmers without any assured source of income were of farmer } \\
\text { attracted more one this system as trees offered an insurance against risk. }\end{array}$ \\
\hline 06 & Access to market & $\begin{array}{l}\text { Presence of an assured market for khoir products was a confidence } \\
\text { booster. }\end{array}$ \\
\hline 07 & Land-use history & $\begin{array}{l}\text { In areas taken up for fresh cultivation, retaining khoir trees or encouraging } \\
\text { natural regeneration was accorded priority. }\end{array}$ \\
\hline
\end{tabular}


rotation period, it could be due to excessive shading by un-pruned trees or lodging of rice crop because of its excessive vegetative growth consequent to increase nutrient availability below tree canopies. Both these situations can be controlled through proper tree management practices. Furthermore, under farmers' conditions in Rajshahi region, trees on farms are of uneven age; a mixture of trees of various age classes is common. Thus, the khoir + rice system seems to be biologically sustainable. Farmers' adoption of the system on a continuous, long-term basis also points to the same conclusion.

The socioeconomic aspects of this system are more unique than its biophysical aspects. Crop cultivation under or along with khoir trees as practised in Rajshahi region is an excellent example of a traditional cropland agroforestry system, the value of which has been known to farmers for centuries, but has not been recognized well by development agencies. A study of this traditional system gives clear indications as to why farmers do what they do in terms of adoption of farming practices. Our survey and interaction with farmers revealed that farmers are fully aware, in their own terms of perception and understanding, of the biophysical advantages of the system. Even more importantly, their decision to continue with this low-input system - the knowledge about which was perhaps passed down to them along with the land by their forefathers - is a manifestation of their adaptation to prevailing socioeconomic factors. The ease of establishment of Khoir seedlings, the low cost of its maintenance, and less vulnerability to any serious pest or disease, easy marketability of prod- ucts rated high in the farmer's preference for khoir. Furthermore, the tree is not easily browsed or grazed by cattle because of its thorny nature.

Farmers of Rajshahi recognize that khoir wood is inferior in quality to that of better-known timber species. Yet, they appreciate the versatility of the wood for a variety of farm uses such as construction of bullock-cart wheels and ploughshares, for which wood of other 'better-quality' species may not be the best suited though its prime economic use to them is for production of lali or katha. They also get pitch khoir as by product of katha (red dye stuff for textiles and paper production).

Regarding future of this system, it is obvious that unless the economic structure of the region is transformed through a miracle of some sort, farmers, especially the poorer ones, are likely to continue the system. It behooves the development community, therefore, to accept this reality and focus some attention on this system and the farming community that practices it. The khoir + rice system of Rajshahi region offers a challenge as well as an opportunity for both scientists and development experts.

\section{Conclusion}

The resource-poor farmers of Rajshahi region have planted and retained khoir trees on their rice fields for generations even before the advent of late 20th century interests in agroforestry and other forms of tree planting on farms. The practice seems to have undergone little change from their traditional past except for occasional use of fertilizers and possibly some use 
of improved rice varieties. The multiple products and services offered by the tree and the relative ease of managing the trees on crop fields without causing any immediate or long-term reduction in crop yield seem to be the most important factors that encourage the farmers to continue this traditional practice. Furthermore, farmers have secure tenure rights to their land, which is a major factor supporting long-term farm-activities such as tree planting. The system analysis envisages that adoption of tree-planting by farmers is likely to happen if they perceive it as satisfying their domestic consumption, income, or farm security needs; if they have secure land tenure; and if the trees are easy to establish and manage. The concept of integrated rural economy in operation is clearly visible when the cross linkages between the household, animal component, farming system and market are examined. For farmers of small and marginal holdings whose annual farm income is directly affected by the presence of khoir trees in their fields, the tree has a special significance and is a symbol of economic and ecological stability. These time-tested systems offer a challenge to scientists and development experts just as they are a tradition and opportunity to the farmers of Rajshahi region of Bangladesh.

\section{References}

Bremen, H. and J.J. Kessler, (1995). Woody Plants in Agro-Ecosystems of Semi-Arid Regions.Springer Verlag, Berlin

Chambers, R., A. Pacey, L.A. Thrupp (eds.), (1989). Farmer First: Farmer Innovation and Agricultural Research. Intermediate Technology Publication, Lon- don, UK.

Ferdouse N, A.T.M.R. Hoque and M.A. Kader, (2009). Production, Processing and Marketing of Khoir (Acacia catechu), an important non timber forest product in Rajshahi Division of Bangladesh. Int.j.for.Usuf.Mngt., 19(2):77-85.

Garrity, D.P., F.K. Akinnifesi, O.C. Ajay, S.G. Weldesemayat, J.G. Mowo, A. Kalinganire, M. Larwanou, J. Bayala, (2010). Evergreen agriculture: a robust approach to sustainable food security in Africa. Food Security, 2:197-214

Hasanuzzaman M. , M. Hossain, M. Saroar, (2014). Floristic composition and management of cropland agroforest in southwestern Bangladesh. Journal of Forestry Research, 25(3): 597-604.

Hildebrand, P.E., (1981). Combining disciplines in rapid appraisal: the Sondeo approach. Agricultural Administration, 8: 423-432.

Hocking, D. and K. Islam, (1995). Trees in Bangladesh paddy fields. 2. Survival of trees planted in crop fields. Agrofor Syst., 31: 39-57.

Husnah, N., M.S.S. Ali, D. Salamn, P. Hijjang , F. Djufry, A. Amrawaty, (2014). Merging Indigenous and Modern Knowledge in Agricultural Development. International Journal of Agriculture System (IJAS), 2(2):141-151.

Jambulingam, R. and E.C.M. Fernandes, (1988). Multipurpose trees and shrubs in Tamil Nadu State (India). Agrofor Syst., 4: 17-32.

Khybri, M.L., R.K. Gupta, R. Sewa and H.P.S. Tomar, (1992). Crop Yields of rice and wheat grown in rotation as in- 
ter crops with three tree species in the outer hills of western Himalayas. Agrofor. Syst., 17: 193-204.

Koohafkan, P., A.M. Alteri, H.E. Gimenz, (2012). Green Agriculture: foundations for biodiversity, resilient and productive agricultural systems. Int J Agric Sustain, 10:61-75.

Nair, P.K.R. (ed), (1989). Agroforestry Systems in the Tropics. Kluwer, Dordrecht, The Netherlands.

Nair, P.K.R. (1993). Introduction to Agroforestry. Kluwer, Dordrecht, The Netherlands,

Nair, P.K.R., (1999). Agroforestry research at a crossroads. Annals of Arid Zone, 38: 415-430.

Nair, P.K.R., R.J. Buresh, D.N. Mugendi and C.R. Latt, (1989). Nutrient cycling in tropical agroforestry systems: myths and science. In Agroforestry in Sustainable Agricultural Systems, Eds., Buck, L.E., J.P. Lassoie and E.C.M. Fernandes, CRC Press, Boca Raton, FL, USA, pp: 1-31.

Poffenberger, M., B. McGean, A. Khare and J. Campbell, (1992). Joint Forest Management Field Methods Manual. Vol II. SPWD, Copernicus Marg, New Delhi.

Puri, S., S. Singh and A. Kumar, (1994). Growth and productivity of crops in association with an Acacia catechu tree belt. J Arid Environ., 27, 37-48.

Rao, M.R., P.K.R. Nair, C.K. Ong, (1998). Biophysical interactions in tropical agroforestry systems. Agrofor. Syst., 38: 3-50.

Rahman, G.M.M. and Alam, M.J., (2007). Composotion and benefit of cropland agroforestry practices practiced in Rajshahi district. J.Agrofor.Environ., 1(2):149-153.

Schroth, G. (1999). A review of belowground interactions in agroforestry focussing on mechanisms and management options. Agrofor. Syst., 43: 5-34.

Shankaranarayanan, K.A., L.N. Harsh, S. Kathju, (1987). Agroforestry in the arid zones of India. Agrofor. Syst., 5: 69-88.

Tejwani, K.G. (ed.), (1994). Agroforestry in India. Oxford \& IBH, New Delhi, India.

Vandenbelt, R.J. (ed.),(1992). Faidherbida Albida in the West African Semi-arid Tropics. ICRISAT, Patencheru, India, 206 pp.

Van Noordwijk, M., G. Lawson, J.J.R. Groot and K. Hairiah, (1996). Root distribution in relation to nutrients and competition. In Tree-Crop Interactions - A Physiological Approach, Eds., Ong C.K. and P.A. Huxley, CAB International, Wallingford, UK. pp: 319-364.

Viswanath, S., P.K. Kaushik, D.K. Pandey, S. Amit, (1998). Effect of Acacia catechu (L.) Willd Ex. Del. on rainfed rice crop in Chhattisgarh, Madhya Pradesh. Annals of Forestry, 6: 103-109.

Young, A., (1997). Agroforestry for Soil Conservation, 2nd ed. CABI, UK 177. 